\title{
Selection of methods used for analyzing the standard time needed to complete the assembly process by means of a fuzzy analytic hierarchy process
}

\author{
Robert Cieślak ${ }^{1 *}$ and Marcin Suszyński ${ }^{2}$ \\ ${ }^{1}$ State University of Applied Sciences in Konin, Faculty of Engineering \\ ${ }^{2}$ Poznan University of Technology, Faculty of Mechanical Engineering and Management
}

\begin{abstract}
This paper is a review of four main methods of analyzing the standard time needed to complete a given job: chronometric analysis, working-day activity study (working-day photo), work sampling observations, and analysis of basic motions. Thanks to the application of FAHP (Fuzzy Analytic Hierarchy Process) method, the values of weighted coefficients were obtained which describe the importance of selecting the criteria of the choice of methods used to analyze the standard time in the assembly process. In the summary paragraph of this paper, the results of analyzing the criteria are discussed.
\end{abstract}

\section{Analysing the standard time for a given job}

\subsection{General issues concerning the standard time for a given job}

Work can be defined as activities requiring mental and physical efforts, the purpose of which is to produce goods and provide services that meet human needs.

In everyday life an important role is played by gainful work, which is a factor determining people's daily rhythms. From the economic point of view, working time is, besides the achieved results, a measure of the amount of work. Working time also determines the necessary part of work performed by society, which everyone ought to contribute to the production of goods and services which are essential for life and for everyone's development and society.

The Polish employment code establishes that working time ought to be understood as the time during which an employee is at the employer's disposal in the workplace or in another place where an employee does their work [1].

As for as working time is concerned, standards setting its upper limit should be determined. Therefore, the length of working time of an employee can be shorter than or equal to the standard, but it cannot be longer.

\footnotetext{
${ }^{*}$ Corresponding author: robertcieslak@wp.pl
} 
In the engineering industry, working time standard is a technically justified amount of time necessary for a specified scope of work to be performed in given technicalorganizational conditions in the workplace, by specified number of workers with specified qualifications [2]:

$$
\mathrm{t}=\mathrm{t}_{\mathrm{pz}}+\mathrm{n} \cdot \mathrm{t}_{\mathrm{j}}
$$

where:

$\mathrm{t}$ - time standard,

$\mathrm{t}_{\mathrm{pz}}$ - set-up time (preparatory - finishing time),

$\mathrm{n}$ - the number of product units in a series manufactured with one setting of a machine tool,

$\mathrm{t}_{\mathrm{j}}$ - unit time.

\subsection{Research into work practices}

Working time analysis involves using methods and experience in analysing and developing work systems in order to facilitate work practices, taking into consideration the following: productivity and needs of people as well as cost-effectiveness of a company.

Analysis and measurements are aimed at, among other things (and provided that measurement and/or control system is acceptable [3]), establishing the real workflow (the stages in a particular work process) and the way the work was performed, revealing time losses resulting from the used method of work (determining production reserves), establishing rational ways and methods of work as well as the necessary time to perform it [4].

\section{Methods of working time analysis}

In industrial practices, various methods of time-use are applied depending on the purpose and the subject matter of the research. The most commonly used techniques of work standardization include: chronometric analysis, working-day activity study (working-day photo), work sampling observations, and analysis of basic motions - MTM [5].

The results obtained from working time analysis constitute the material for the following:

- working out time standards for typical activities and workers' motions, which later will constitute a source of numerical data to establish work standards,

- analysing methods of work in order to rationalize, that is, searching for better ways of using specific tasks and activities as well as their right sequence in terms of efficiency,

- analysing multi-machine working conditions as one of the ways to use the working time better,

- observing flow production lines to achieve better synchronization of them,

- working out technical standards of time for performing specific operations in case there are no appropriate standards (analytical-measuring method of establishing standards),

- comparing the ability achieved by individual workers or discovering reasons for their inability to achieve $100 \%$ of the work standard $[4,6]$.

\subsection{Chronomietrtic analysis (stop-watch study analysis)}

It is a method of measuring repetitive operations or their elements (task, activity, workers' motion) designed to determine, on the basis of the specific number of measurements, the 
appropriate time of their duration and their rational completion at a normal pace of work. Chronometric observations can be carried out continuously or randomly [8].

In order to make labour-intensive chronometric measurements it is necessary that specially prepared (trained) workers should be equipped in appropriate measuring instruments. The most commonly used measuring instruments include: watches and stopwatches, self-recording measuring instruments, photo- and cinematographic equipment, automatic devices for analysis of working time and automatic control devices.

Depending on the number of employees whose work is observed, the chronometric analysis can be carried out for individual workers or a group of them. There are also various types of chronometric analysis, including the continuous, random and cyclical ones. When it comes to the practical application, the following types of chronometric analysis can be enumerated: moving, photographic or selective [5].

Table 1 shows advantages and disadvantages of chronometric analysis.

Table 1. Advantages and disadvantages of chronometric analysis [7, 5].

\begin{tabular}{|c|c|}
\hline Advantages & Disadvantages \\
\hline $\begin{array}{l}\text { - the most faithful recording of temporal } \\
\text { sequence of events (reliability), } \\
\text { - creating a system of information in complete } \\
\text { compliance with the real sequence of events, } \\
\text { - making sure that information is promptly } \\
\text { available, which means that every piece of } \\
\text { information obtained in the measurement is } \\
\text { available within a designated period of time, } \\
\text { - keeping an accurate record of events on the } \\
\text { basis of the information derived from } \\
\text { authoritative sources (reliable), } \\
\text { - simplifying and increasing the pace of } \\
\text { preparing information so that it can be used in } \\
\text { decision-making processes. }\end{array}$ & $\begin{array}{l}\text { - performing measurements is } \\
\text { considerably labour-intensive, } \\
\text { - high costs of performing } \\
\text { measurements, } \\
\text { - high focus of attention on the part of } \\
\text { a timekeeper while measuring with the } \\
\text { use of a stopwatch without a drag } \\
\text { pointer, } \\
\text { - the possibility of lengthening the } \\
\text { time of making a product by a worker }\end{array}$ \\
\hline
\end{tabular}

Figure 1 presents an algorithm showing the procedure in chronometric analysis, worked out on the basis of the published literature [5].

\subsection{Working-day activity study (working-day photograph)}

Working-day activity study involves continuous observing and performing measurements of time used at the workstation while taking into consideration the time during which employees worked and had breaks. The length of time needed for obtaining one photograph (one self-contained working-day activity study) usually overlaps with a period of one working shift of its part. The purpose of the photograph is to determine the degree to which the working time was used and the value of its real usage which is necessary to work out the standard [10].

The results of working-day activity study are used for improving the organization of production (the organization of work and workstations), for improving material, technical, and organizational production security and they are also the starting point for developing time standards and machine operation norms [14].

In order to obtain the working-day photograph, two basic systems of registering time are used: the tabular and scale systems. 


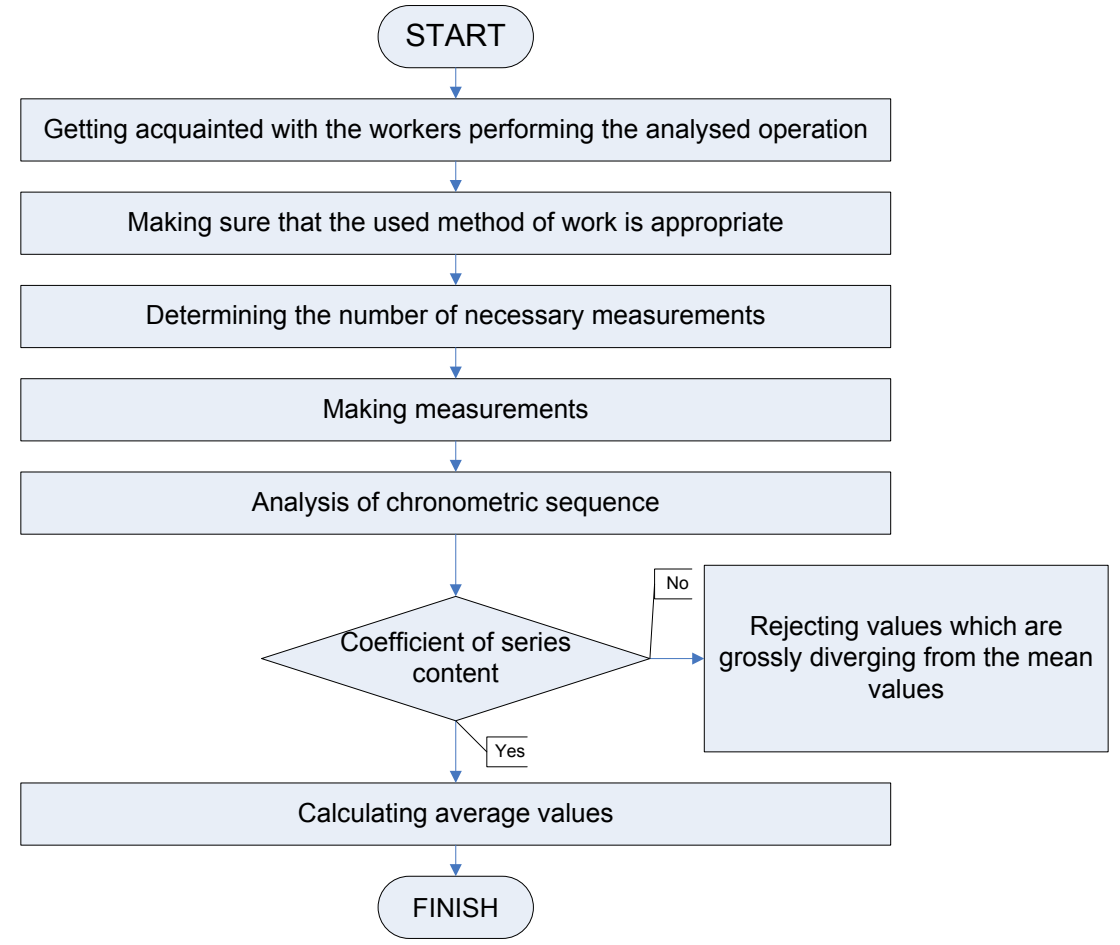

Fig. 1. Procedural algorithm [the author's own study - drawing a diagram].

A worker, machine, a worker and a machine at the same time, and also a team of workers or a team of workers and machines at the same time are usually subject to observations. Depending on the tasks and the kind of objects being observed, the following types of photographs of working time can be distinguished: individual, group, team, a photograph of one worker operating more machines and finally a self-photograph (the study performed by the worker himself/herself [5].

Table 2 shows advantages and disadvantages of working-day activity study.

Table 2. Advantages and disadvantages of working-day activity study $[5,13,14]$.

\begin{tabular}{|c|c|}
\hline Advantages & Disadvantages \\
\hline $\begin{array}{l}\text { - the possibility of doing research even at } \\
\text { six workstations at the same time with one } \\
\text { person simultaneously making } \\
\text { observations and registering data, } \\
\text { - reliability of mean values which are } \\
\text { taken into account while determining } \\
\text { additions of auxiliary time, } \\
\text { - keeping an accurate record of events (the } \\
\text { length of time employees work and take } \\
\text { breaks). } \\
\text { - simplifying and increasing the pace of } \\
\text { preparing information so that it can be } \\
\text { used in decision-making processes. }\end{array}$ & $\begin{array}{l}\text { - performing measurements is considerably } \\
\text { labour-intensive, } \\
\text { - high costs of performing measurements, } \\
\text { - high focus of attention on the part of a } \\
\text { timekeeper while measuring with the use of } \\
\text { a stopwatch without a drag pointer, } \\
\text { - it does not take account of a random choice } \\
\text { of registered real times } \\
\text { - the possibility of lengthening the time of } \\
\text { making a product by a worker }\end{array}$ \\
\hline
\end{tabular}

Figure 2 presents an algorithm showing the procedure in a working-day activity study, worked out on the basis of the published literature [5]. 


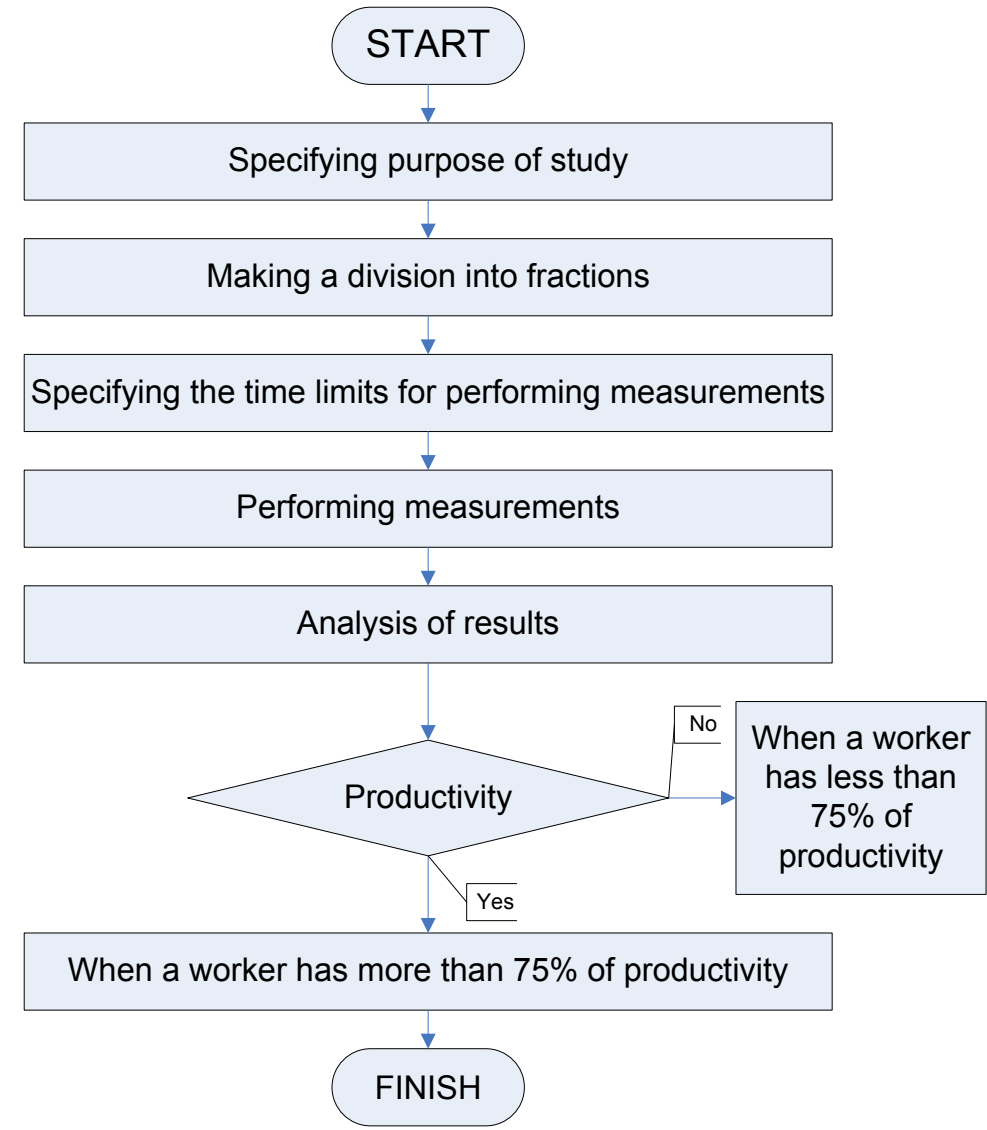

Fig. 2. Procedural algorithm [the author's own study - drawing a diagram].

\subsection{Work sampling observations}

Work sampling observations have become the basic method designed to analyse working time and they are supplanting the traditional Working-day activity study. It involves establishing the frequency of predefined types of event sequences in one or several work systems, by means of brief observations. These observations can be made on both workers and means of production.

The chronometer (stopwatch) is not used in work sampling observations and, what is more, continuous observations by the observer at workstations are not necessary. The reason for this is that this method involves using the calculus of probability for observations which are made (recorded) at specified intervals.

In order to transfer the results of work sampling analysis, carried out on a sample, onto the whole studied group with a satisfactory reliability, the following conditions have to be fulfilled:

- sample has to be representative, that is, it has to recreate the relations and proportions that occur in the whole studied group,

- any event occurring in the whole studied group has to have an equal probability of being found in the analysed sample [5].

The programme of work sampling study can be divided into several stages: 
- preparing for the analysis, which means establishing the purpose and describing types of workflows (event sequences),

- determining the necessary scope of observations,

- determining time points of walking rounds (visits).

- calculating the necessary number of observations,

- making observations,

- the analysis of observation results, including the indirect analysis which is aimed to make sure whether the established number of observation scope is accurate or there is a serious error in the estimation,

- the final analysis.

Table 3 shows advantages and disadvantages of work sampling study.

Table 3. Advantages and disadvantages of work sampling study [8, 9, 14, 15].

\begin{tabular}{|c|c|}
\hline \multicolumn{2}{|c|}{ Work sampling study } \\
\hline Strengths & Weaknesses \\
\hline $\begin{array}{l}\text { - performing measurements without } \\
\text { measuring instruments, } \\
\text { - the person carrying out the analysis does } \\
\text { not have to continuously observe } \\
\text { workstations, } \\
\text { - the possibility to observe a number of } \\
\text { randomly selected workstations } \\
\text { simultaneously, } \\
\text { - the possibility to stop and resume making } \\
\text { observations periodically, } \\
\text { - easy analysis of measurements, } \\
\text { - control charts which make it possible to } \\
\text { supervise the process of performing } \\
\text { measurements, } \\
\text { - the possibility to quickly discover errors } \\
\text { made while performing measurements, } \\
\text { - from } 40 \% \text { to } 70 \% \text { of the time spent on } \\
\text { performing time measurements in } \\
\text { comparison to other fine-tuned methods of } \\
\text { measuring/determining the time } \\
\text { consumption of assembly work. }\end{array}$ & $\begin{array}{l}\text { - it is difficult to check a single record in } \\
\text { terms of substance because it constitutes a } \\
\text { single unrepeatable sequence of activities, } \\
\text { - it is impossible to check and compare a } \\
\text { report on work sampling study with a } \\
\text { report on time measurement, } \\
\text { - lack of information on the evaluation of } \\
\text { the pace of work, } \\
\text { - lack of information on types of activity } \\
\text { sequences which comprise less than } 1 \% \text { of } \\
\text { all the records, } \\
\text { - it is difficult to determine the causes of } \\
\text { breaks at work resulting from disruptions, } \\
\text { - it is impossible to carry out a detailed } \\
\text { analysis of reasons for workers' absences } \\
\text { at their workstations. }\end{array}$ \\
\hline
\end{tabular}

Figure 3 presents an algorithm showing the procedure in work sampling study, worked out on the basis of the published literature [5].

\subsection{Basic motion analysis}

Basic motion analysis, also referred to as MTM (Methods Time Measurement), is one of the most commonly used methods of normalizing the length of manual operation time. MTM (Methods Time Measurement) was mainly developed from combining the methodological basics of analyzing motions and their duration time. At the same time, this method is used for improving the flow of work, determining the times of work performance and classifying (determining the level of difficulty). MTM (Methods Time Measurement) assumes that every human manual activity can be divided into basic motions made by the torso and limbs and it also assumes the time consumption of the activity is a sum of duration times of motions which the activity consists of. There are three main groups of 
motions in this method: 9 hand movements, 2 eye movements and 15 body and leg movements.

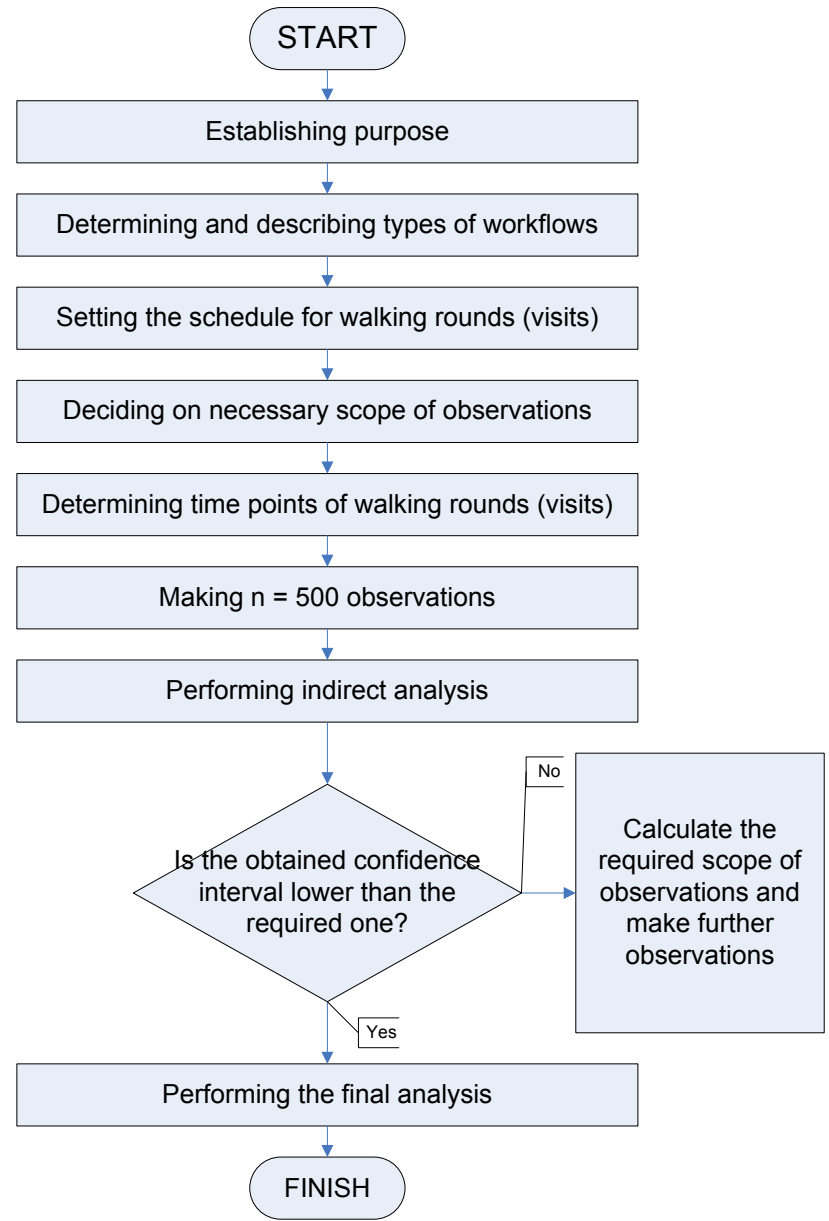

Fig. 3. Procedural algorithm [the drawing made by the author on the basis of literature].

This method does not limit itself to these 26 basic movements. In the first group, the movements are divided into categories, and these, in some cases, can be divided into classes, depending on their character and the conditions in which they are made. Time values are assigned to these categories and classes of movements in special tables of MTM method. The basic time unit in MTM (Methods Time Measurement) method is 1 TMU (Time Measurement Unit) $=0.0006$ min.

In practice, the use of this method requires hiring qualified workers who were acquired theoretical knowledge during training courses and who possess a great deal of practical experience.

MTM (Methods Time Measurement) method has its own variations which take account of the level of element integration. The following variations can be distinguished: MTM - 1 method for duration times of operations lasting 0,1-0,5 min and significant repeatability of jobs (multi-series and mass production), MTM - 2, where duration times of operations last 0,5-5 min, and MTM - 3 which is used in special jobs [5].

Tab. 4 shows advantages and disadvantages of MTM method. 
Table 4. Advantages and disadvantages of MTM (Methods Time Measurement) method [16].

\begin{tabular}{|c|c|}
\hline Advantages & Disadvantages \\
\hline $\begin{array}{l}\text { - the possibility to design the most } \\
\text { economical manufacturing process in } \\
\text { specified production conditions before } \\
\text { launching the production of a given product } \\
\text { - improving the work process } \\
\text { - numerical and letter symbols make it } \\
\text { possible to record performed operations } \\
\text { accurately and easily } \\
\text { - normative time values in basic time systems } \\
\text { are given, depending on parameters (factors) } \\
\text { influencing them, such as the length of motion } \\
\text { or performance control } \\
\text { - operations are easy to analyse } \\
\text { - the possibility to determine a precise time } \\
\text { needed to perform a job or its elements } \\
\text { - it is possible and easy to choose an optimal } \\
\text { way of designing or improving a given work } \\
\text { process } \\
\text { - uniform pace for determined standards } \\
\text { - it gives time values before launching } \\
\text { production, thus eliminating expensive } \\
\text { amendments } \\
\text { - improving already existing methods, and } \\
\text { procedures constitute additional help and } \\
\text { materials for designing new procedures }\end{array}$ & $\begin{array}{l}\text { - it is necessary to provide users of this } \\
\text { method with on-site theoretical and } \\
\text { practical training courses } \\
\text { - there are limited possibilities to analyze } \\
\text { the methods and activities of office } \\
\text { workers and people operating machinery } \\
\text { or equipment and as regards improving } \\
\text { and standardizing times of jobs } \\
\text { characterized by low pace of production } \\
\text { (non-repetitive processes, single and } \\
\text { small-scale production) this method is } \\
\text { too precise and labour-intensive as a } \\
\text { research tool. }\end{array}$ \\
\hline
\end{tabular}

\section{The analysis of the research into normalizing the working time in the assembly process by means of analytic hierarchy process}

\subsection{Description of FAHP method}

FAHP is a Fuzzy Analytic Hierarchy Process used in developing decision-making models and its purpose is to determine values of weighted coefficients that specify the importance of individual criteria. At the same time, thanks to the use of FAHP, the criteria of lesser importance can be eliminated while selecting auxiliary tools for managing tacit knowledge, $[16,17]$.

In the analyzed case the choice is made of the most important criteria that a company should take account of while selecting a method of studying the working time in the assembly process. Making an evaluation of objective elements will make it possible to determine the importance of defined criteria of selecting a solution. The preference scale should be defined while determining the relation of relative dominance. According to Nydick i Hill [30], the fuzzy number $\tilde{a}=(\mathrm{l}, \mathrm{m}, \mathrm{u})$ with a triangular membership function can be assigned to a linguistic variable that describes the relationships. The triangular fuzzy number $\tilde{\mathrm{a}}=(\mathrm{l}, \mathrm{m}, \mathrm{u})$ is defined within the range $[l, u]$, and its membership function assumes the value which is equal to 1 in point $\mathrm{m}$ (fig. 4 ). The preference scale is presented in tab. 5. 


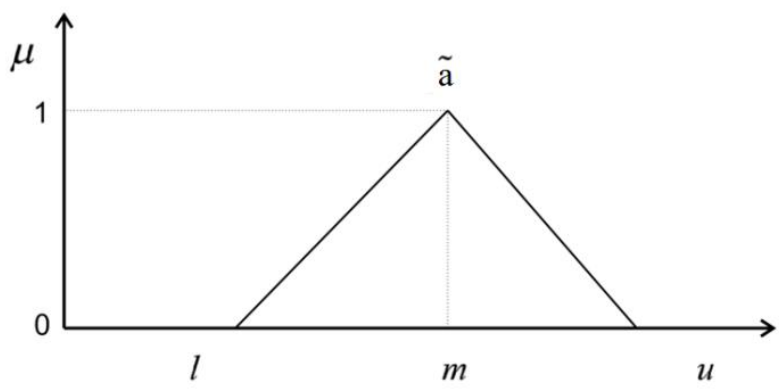

Fig. 4. Triangular fuzzy number $\tilde{a}=(1, \mathrm{~m}, \mathrm{u})$.

Table 5. Fuzzy scale used in FAHP method.

\begin{tabular}{|c|c|c|}
\hline Relative dominance & $\begin{array}{c}\text { FAHP } \\
\text { (Triangular fuzzy scale) }\end{array}$ & $\begin{array}{c}\text { FAHP } \\
\text { (Triangular fuzzy scale } \\
\text { - inverse) }\end{array}$ \\
\hline Equal importance & $(1,1,1)$ & $(1,1,1)$ \\
\hline Moderate importance & $(1,3,5)$ & $(1 / 5,1 / 3,1 / 1)$ \\
\hline Strong importance & $(3,5,7)$ & $(1 / 7,1 / 5,1 / 3)$ \\
\hline Very strong importance & $(5,7,9)$ & $(1 / 9,1 / 7,1 / 5)$ \\
\hline Extreme importance & $(7,9,9)$ & $(1 / 9,1 / 9,1 / 7)$ \\
\hline
\end{tabular}

Table 6. The elements of matrix for comparison of criteria selection for analyzing the method of working time study [the author's own study].

\begin{tabular}{|c|c|c|c|c|c|}
\hline Kryteria & NK & NC & CO & ND & LP \\
\hline NK & $(1,1,1)$ & $(1,3,5)$ & $(1,3,5)$ & $(1 / 7,1 / 5,1 / 3)$ & $(3,5,7)$ \\
\hline NC & $(1 / 5,1 / 3 / 1)$ & $(1,1,1)$ & $(1,3,5)$ & $(1 / 7,1 / 5,1 / 3)$ & $(1,3,5)$ \\
\hline CO & $(1 / 5,1 / 3 / 1)$ & $(1 / 5,1 / 3 / 1)$ & $(1,1,1)$ & $(1 / 7,1 / 5,1 / 3)$ & $(1,3,5)$ \\
\hline ND & $(3,5,7)$ & $(3,5,7)$ & $(3,5,7)$ & $(1,1,1)$ & $(5,7,9)$ \\
\hline LP & $(1 / 7,1 / 5,1 / 3)$ & $(1 / 5,1 / 3,1)$ & $(1 / 5,1 / 3,1)$ & $(1 / 9,1 / 7,1 / 5)$ & $(1,1,1)$ \\
\hline
\end{tabular}

$\mathrm{NK}$ - the lowest cost, $\mathrm{NC}$ - the shortest time, $\mathrm{CO}$-observation continuity, ND - the highest accuracy, ŁP - easiness of conducting the study

The geometric mean of evaluations for criterion $\mathrm{NK}$, in accordance with the relationships in FAHP assumes the following value:

$$
\begin{gathered}
N \widetilde{K}=r \tilde{1}=(\tilde{a} 11 \times \tilde{a} 12 \times \tilde{a} 13 \times \tilde{a} 14 \times \tilde{a} 15)^{\frac{1}{5}} \\
N \widetilde{K}=r \tilde{1}=\left(\left(1 \times 1 \times 1 \times \frac{1}{7} \times 3\right)^{\frac{1}{5}},\left(1 \times 3 \times 3 \times \frac{1}{5} \times 5\right)^{\frac{1}{5}},\left(1 \times 5 \times 5 \times \frac{1}{3} \times 7\right)^{\frac{1}{5}}\right) \\
N \widetilde{K}=r \tilde{1}=(0,84412 ; 1,55184 ; 2,25519)
\end{gathered}
$$

The values for the other criteria were obtained in an analogous manner to the formula given above:

$$
\begin{gathered}
N \tilde{C}=r \tilde{2}=\left(\left(\frac{1}{5} \times 1 \times 1 \times \frac{1}{7} \times 1\right)^{\frac{1}{5}},\left(\frac{1}{3} \times 1 \times 3 \times \frac{1}{5} \times 3\right)^{\frac{1}{5}},\left(1 \times 1 \times 5 \times \frac{1}{3} \times 5\right)^{\frac{1}{5}}\right) \\
N \tilde{C}=r \tilde{2}=(0,49111 ; 0,90288 ; 1,52814)
\end{gathered}
$$




$$
\begin{gathered}
C \tilde{O}=r \tilde{3}=\left(\left(\frac{1}{5} \times \frac{1}{5} \times 1 \times \frac{1}{7} \times 1\right)^{\frac{1}{5}},\left(\frac{1}{3} \times \frac{1}{3} \times 1 \times \frac{1}{5} \times 3\right)^{\frac{1}{5}},\left(1 \times 1 \times 1 \times \frac{1}{3} \times 5\right)^{\frac{1}{5}}\right) \\
C \tilde{O}=r \tilde{3}=(0,35595 ; 0,58181 ; 1,10756) \\
N \widetilde{D}=r \tilde{4}=\left((3 \times 3 \times 3 \times 1 \times 5)^{\frac{1}{5}},(5 \times 5 \times 5 \times 1 \times 7)^{\frac{1}{5}},(7 \times 7 \times 7 \times 1 \times 9)^{\frac{1}{5}}\right) \\
N \widetilde{D}=r \tilde{4}=(2,66726 ; 3,87615 ; 4,98778) \\
七 \tilde{P}=r \tilde{5}=\left(\left(\frac{1}{7} \times \frac{1}{5} \times \frac{1}{5} \times \frac{1}{9} \times 1\right)^{\frac{1}{5}},\left(\frac{1}{5} \times \frac{1}{3} \times \frac{1}{3} \times \frac{1}{7} \times 1\right)^{\frac{1}{5}},\left(\frac{1}{3} \times 1 \times 1 \times \frac{1}{5} \times 1\right)^{\frac{1}{5}}\right) \\
Ł \tilde{P}=r \tilde{5}=(0,22937 ; 0,31647 ; 0,58181)
\end{gathered}
$$

Consequently, the following was obtained:

$$
\tilde{r} 1+\tilde{r} 2+\tilde{r} 3+\tilde{r} 4+\tilde{r} 5=(4,58781 ; 7,22915 ; 10,46048)
$$

The weight of criterion ,NK" was calculated in the following way:

$$
\widetilde{w} 1=\tilde{r} 1 \times(\tilde{r} 1+\tilde{r} 2+\tilde{r} 3+\tilde{r} 4+\tilde{r} 5)^{-1}=(0,08069 ; 0,21466 ; 0,49156)
$$

Then, the weight for the remaining criteria was calculated in an analogous manner to the formula given above:

$$
\begin{aligned}
& \widetilde{w} 2=\tilde{r} 2 \times(\tilde{r} 1+\tilde{r} 2+\tilde{r} 3+\tilde{r} 4+\tilde{r} 5)^{-1}=(0,04694 ; 0,12489 ; 0,33308) \\
& \widetilde{w} 3=\tilde{r} 3 \times(\tilde{r} 1+\tilde{r} 2+\tilde{r} 3+\tilde{r} 4+\tilde{r} 5)^{-1}=(0,03402 ; 0,08048 ; 0,24141) \\
& \widetilde{w} 4=\tilde{r} 4 \times(\tilde{r} 1+\tilde{r} 2+\tilde{r} 3+\tilde{r} 4+\tilde{r} 5)^{-1}=(0,25498 ; 0,53618 ; 1,08718) \\
& \widetilde{w} 5=\tilde{r} 5 \times(\tilde{r} 1+\tilde{r} 2+\tilde{r} 3+\tilde{r} 4+\tilde{r} 5)^{-1}=(0,02192 ; 0,04377 ; 0,12681)
\end{aligned}
$$

The defuzzified values of weights are as follows:

$$
\begin{aligned}
\widetilde{w} 1 & =\frac{1}{3}(0,08069 ; 0,21466 ; 0,49156)=0,26230 \\
\widetilde{w} 2 & =\frac{1}{3}(0,04694 ; 0,12489 ; 0,33308)=0,16830 \\
\widetilde{w} 3 & =\frac{1}{3}(0,03402 ; 0,08048 ; 0,24141)=0,11863 \\
\widetilde{w} 4 & =\frac{1}{3}(0,25498 ; 0,53618 ; 1,08718)=0,62611 \\
\widetilde{w} 5 & =\frac{1}{3}(0,02192 ; 0,04377 ; 0,12681)=0,06416
\end{aligned}
$$

After standardization the weights assume the following values:

$$
w 1=0,21161 ; w 2=0,13578 ; w 3=0,09570 ; w 4=0,50513 ; w 5=0,05176
$$

Thanks to the application of FAHP method, the following importance level of criteria while selecting a method of studying the working time was obtained, respectively:

- criterion importance: ND - the highest accuracy - value: 0,50513,

- criterion importance: $\mathrm{NK}$ - the lowest cost - value: 0,21161,

- criterion importance: $\mathrm{NC}$ - the shortest time - value: 0,13578 ,

- criterion importance: $\mathrm{CO}$ - observation continuity - value: 0,09570,

- criterion importance: $Ł P B$ - easiness of conducting the study - value: 0,05176.

The suggested application of FAHP method makes it possible to make an objective choice of the tool which supports the tacit knowledge management according to the criteria which are difficult to measure. Expressing preferences in the form of fuzzy numbers reflects the uncertainty in formulating judgments in decision-making process. Therefore, a defined order of criteria importance should be taken into consideration while selecting a method of studying the working time. 


\section{Summary and conclusion}

The purpose of this paper is to present the possibility of using Fuzzy Analytic Hierarchy Process (FAHP) in the process of developing a synthetic variable. FAHP (Fuzzy Analytic Hierarchy Process) method takes advantage of experts' opinions in order to determine weighted coefficients specifying the importance of variables. FAHP (Fuzzy Analytic Hierarchy Process) method was used for selecting criteria of the method for studying the working time in the assembly.

The results of the study indicate that, based on the criteria, the highest accuracy is the most important. Then, the lowest cost is the next. The values obtained in the calculations show that the advantage of the highest accuracy over the remaining ones is considerable. The authors of the paper intend to analyze advantages and disadvantages of FAHP (Fuzzy Analytic Hierarchy Process) method in developing more sophisticated technological processes. In order to become convinced that this method can be justifiably used by engineers, the authors intend to analyze more sophisticated technological processes used in assembly work (selecting a technological variant).

\section{References}

1. Kodeks Pracy, art. 128

2. A. Giddens, Socjologia, PWN, Warszawa (2004)

3. M. Diering, K. Dyczkowski, A. Hamrol, Springer International Publishing Switzerland, 368, 415 (2015)

4. REFA., Metody badania prac cz.1 i cz.2, Cieszyńska Drukarnia Wydawnicza, 12 (1984)

5. Z. Jasiński, Zarzadzanie praca - organizowanie, planowanie, motywowanie, kontrola, Agencja Wydawnicza „Placet”, Warszawa, 92 (1999)

6. M.R.L. Varela, J. Trojanowska, S. Carmo-Silva, N.M.L. Costa, J. Machado, Management and Production Engineering Review, 8(2), 69 (2017)

7. H. Mreła, Technika organizowania pracy, wyd. Wiedza Powszechna, Warszawa, 289 (1975)

8. R. Wołk, Podstawy normowania pracy $w$ przemyśle maszynowym, Wydawnictwa Naukowo - Techniczne, Warszawa, (2012)

9. R. Wołek, Strzelecki T.J., Badanie metod i normowanie pracy, Wydawnictwo Politechniki Warszawskiej, Warszawa 39 (1993)

10. H. Mreła, Metody badania pracy - metody i techniki organizatorskie, PWE, Warszawa, 84, (1979)

11. V. Libal i zespół (tłumaczył Jeleń W.), Organizacja $i$ zarządzanie produkcją, Państwowe Wydawnictwo Ekonomiczne, Warszawa 590 (1976)

12. Z. Mikołajczyk, Techniki organizatorskie w rozwiąywaniu problemów zarządzania, PWN, Warszawa (1997)

13. A.P. Muhlemann, J.S. Oakland, K.G. Lockyer, Zarządzanie produkcja i ustugi, PWN, Warszawa (2001)

14. W. Kieżun, Podstawy organizacji i zarządzania, Wydawnictwo Książka i Wiedza, Warszawa 12, 195 (1980)

15. V. Prabhu, G. Martin Helander and V. Shalin, The International journal of Human Factors in manufacturing 5 (2), 151 (1995)

16. D.-Y. Chang, European Journal of Operational Research, 95 (2), 649 (1996)

17. R.L. Nydick, R.P. Hill, International Journal of Purchasing and Materials Management 28 (2) (1992) 
